PRECONFERENCE INSTITUTES

- "New Dimensions in Acquisitions" will be the theme of a $2 \frac{1}{2}$ day Institute June 19 through June 21, 1969, to be held prior to the Annual Conference of the American Library Association in Atlantic City. The sponsor of this Institute is the American Book Publishers Council/Resources and Technical Services Division Joint Committee of the American Library Association.

Innovative approaches to the solutions of library acquisition problems will be emphasized through both traditional print material and the newer non-print materials. Among traditional problems covered in the Institute sessions will be the out-of-print market, periodical subscriptions, gifts and exchanges, and the purchase of paperbacks. Newly emerging techniques for purchasing, such as advance copy plans, blanket orders, and centralized acquisitions will be presented along with modern acquisition techniques using computer processing, the standard book number, and other aspects of scientific management.

The opening address will be by James C. Worthy of the management consultant firm of Cresap, McCormick and Paget. Mr. Worthy's topic will be "Scientific Management" stress-

\section{FOR THE RUSSIAN} BOOK SECTION

\section{Reference and}

\section{Source Material}

- Russian Literature: Classics, Contemporary

- Linguistics and Literary Criticism

- English-Russian and Russian-English Dictionaries

- Russian Language Records, Folk Songs and Dramatic Readings

- Children's Literature

- Books on Art

- Books on Science

- Textbooks on mathematics, geography, natural sciences, history, etc.

- Socio-Economic Literature

- Russian Atlases and Maps

- Soviet Magazines and Newspapers

Inquire about our out-of-print books and back issue magazines.

Write for Catalogs \& Prices

Phone 212 CH 2-4500

FOUR GOHTINENT BOOK GORP. DEPT. 70, 165 FIFTH AVENUE, NEW YORK, N. Y. 10010 ing the need for efficient and economical procedures, research experimentation, and testing of acquisitions systems. Mrs. Elizabeth Rodell of Rice University, for seven years executive secretary of the Resources and Technical Services Division, will be the banquet speaker. Her topic "Performance Goals for the Acquisitions Process."

To register, send name and address, with or without the official application blank, with the registration fee of $\$ 41.00$, to ABPC-RTSD Preconference Institute, American Library Association, 50 East Huron Street, Chicago, Illinois 60611. Please make checks payable to the American Library Association. The Institute is limited to 500 attendees.

The Institute will be held in the Dennis Hotel, Atlantic City. For hotel reservations, use the housing form in the January, 1969 ALA Bulletin. Room reservations will be honored in the block space only until May 1. Request housing in the Lombardy, Mt. Royal or Traymore hotels where space is being reserved for attendees at this institute. Include the statement that you will be attending the ABPCRTSD Preconference Institute. The registration fee covers the costs of luncheons of Thursday and Friday and the banquet Friday evening.

- "New Strategies for Learning: the Impact of Instructional Technology Upon the Junior College" will be the theme of a preconference sponsored by the American Association of Junior Colleges and the Association of College and Research Libraries at Atlantic City, New Jersey, from June 19-21, 1969. Planned to stimulate dialogue between administrators, faculty, librarians and media specialists; the two days of sessions will include demonstrations, concurrent workshops, and contact with resource persons. Major presentations will be made by Dr. Bill J. Priest, Chancellor, Dallas County Junior College District, Dallas, Texas; Dr. Gabriel Ofiesh, Chairman, Department of Educational Technology, Catholic University, Washington, D.C.; Dr. James Zigerell, Dean, TV College, Chicago City College, Chicago, Illinois; and Dr. Carol Zion, Assistant to the Vice-President, Miami Dade Junior College, Miami, Florida.

Maurice B. Mitchell, Chancellor of the University of Denver and former President and Editorial Director of Encyclopaedia Britannica, Inc., will speak at the banquet to be held in connection with the preconference Friday, June 20.

Attendance is limited to 500 persons, and the registration fee, including three meals, is $\$ 50$. Reservation forms and information may be requested from the Association of College and Research Libraries, American Library Association, 50 East Huron Street, Chicago, Illinois 60611 . 